\title{
Demonstration of antibiotic-induced tolerance development in tropical agroecosystems through physiological profiling of sediment microbial communities
}

Agricultural use of antibiotics differs quantitatively and qualitatively in tropical and temperate countries. To gain insight into the nature and magnitude of physiological adaptations prompted by these drugs in microbial communities from tropical agroecosystems, we compared community-level physiological profiles of sediment bacteria from a protected wetland (PV), a pig farm (RD), treated (TIL1) and untreated effluents (TIL2) from a tilapia farm, an estuary close to shrimp farms (CA), and an irrigation channel adjacent to a rice plantation (AZ) exposed to a range of oxytetracycline (OTC) concentrations in Ecoplates $\left(\right.$ Biolog $\left.{ }^{\circledR}\right)$. In addition, we used LC/MS/MS and plate counts to determine the concentration of OTC and the number of OTC-resistant bacteria in the samples, respectively. Water samples collected at RD contained maximum amounts of OTC (640 ng L-1), followed by TIL2 (249 ng

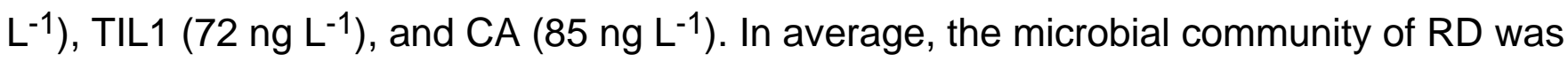
more tolerant to OTC $\left(E_{50}: 14.30 \pm 3.12 \mathrm{mg} \mathrm{L}^{-1}\right)$ than bacteria from CA $\left(8.83 \pm 1.85 \mathrm{mg} \mathrm{LI}^{-}\right.$ 1), TIL2 $\left(\mathrm{EC}_{50}: 4.97 \pm 1.43 \mathrm{mg} \mathrm{L}^{-1}\right)$, TIL1 $\left(4.25 \pm 0.60 \mathrm{mg} \mathrm{L}^{-1}\right), \mathrm{AZ}\left(3.66 \pm 0.97 \mathrm{mg} \mathrm{L}^{-1}\right)$ and PV (3.77 $\left.\pm 0.62 \mathrm{mg} \mathrm{L}^{-1}\right)$. Congruently, PV, AZ, TIL1, CA, TIL2, and RD appeared in that order in a cumulative distribution of individual $\mathrm{EC}_{50}$ values and higher plate counts of bacteria resistant to $10 \mu \mathrm{g} \mathrm{mL}^{-1}\left(5.0 \times 10^{5}-1.5 \times 10^{7}\right)$ and $100 \mu \mathrm{gL}^{-1}$ of OTC $\left(1.5 \times 10^{4}-8.4 \times 10^{5}\right)$ were obtained for RD than for the other sites $\left(10 \mu \mathrm{g} \mathrm{ml}^{-1}: 4.8 \times 10^{4}-3.3 \times 10^{5}\right.$ and $100 \mu \mathrm{g} \mathrm{mL}^{-1}$ : $\left.1.0 \times 10^{2}-4.4 \times 10^{3}\right)$. These results are compatible with a scenario in which the basal level of tolerance to OTC that characterizes pristine environments (PV) is amplified in proportion to the intensity of antibiotic exposure (agriculture $<$ aquaculture $<$ swine farming). 
1 María

2 Arias-Andrés

3 Instituto Regional de Estudios en Sustancias Tóxicas (IRET), Universidad Nacional

4 Apartado Postal 86-3000, Heredia, Costa Rica

5 Clemens

6 Ruepert

7 Instituto Regional de Estudios en Sustancias Tóxicas (IRET), Universidad Nacional

8 Apartado Postal 86-3000, Heredia, Costa Rica

9 Fernando

10 García-Santamaría

11 Centro de Investigación en Enfermedades Tropicales (CIET) \& Facultad de Microbiología,

12 Universidad de Costa Rica

13 San José, Costa Rica

14 César

15 Rodríguez

16 Centro de Investigación en Enfermedades Tropicales (CIET) \& Facultad de Microbiología,

17 Universidad de Costa Rica

18 San José, Costa Rica

19 Corresponding author: César Rodríguez

20 Mail address: Universidad de Costa Rica. Facultad de Microbiología. Sección de Bacteriología

21 General. San Pedro de Montes de Oca 2060. San José. Costa Rica

22 Phone: +506-2511-8616

23 Fax: +506-2253-0066

24 e-mail: cesar.rodriguezsanchez@ucr.ac.cr 


\section{Introduction}

Antibiotics from diverse families have been recently found in sewage treatment plants, sewage sludge, surface waters, sediments, and groundwater all over the world (Heberer 2002; Hernando et al. 2006). Many of these compounds should be regarded as high-priority emerging pollutants on account of their synthetic nature, abnormal environmental levels (Kümmerer 2009), long persistence, and lack of toxicological and ecotoxicological information or published health and environmental standards.

As a result of their historical efficacy in human medicine, low cost, and extensive commercialization, different tetracyclines have been used for decades in the control of bacterial diseases of fruits, vegetables and animals (Kümmerer 2009), for growth promotion of poultry and livestock (Pijpers et al. 1991), and as infection control agents in aquaculture (Avisar et al. 2009). These substances tend to be poorly absorbed by animals (Lunestad and Goksayr 1990; Seyfried et al. 2010); hence they are administered in high concentrations and after excretion they accumulate in agricultural soils (Piotrowska-Seget et al. 2008) and fishpond sediments (Lalumera et al. 2004; Maki et al. 2006), where they can be mobilized outside the farms or persist for up to 5 months (Carson et al. 2002; Rubert and Pedersen 2006).

Our study focuses on the environmental effects elicited by oxytetracycline (OTC) for several reasons. First of all, OTC is widely used in tropical agriculture (Rodríguez 2008). Second, studies of acute and chronic toxicity of OTC in microorganisms, invertebrates, and fish urge closer monitoring and further toxicological research on this substance (Park and Choi 2008). Third, OTC was heavily consumed and linked to very high hazard quotients in a recent risk assessment performed in the area studied here (de la Cruz et al. 2014). Finally, there are reports of the finding of OTC-resistant bacteria and tet genes in crops (Rodríguez et al. 2006) and farm soil from Costa Rica (Rodríguez et al. 2007), of the detection of $\mathrm{mg} \mathrm{kg}^{-1}$ of OTC and other tetracyclines in locally-produced animal feed (Gutiérrez et al. 2010; Granados et al. 2012), and of ng L $\mathrm{L}^{-1}$ of this substance in surface waters across this tropical country (Spongberg et al. 2011). Molecular methods have proved that the structure of microbial communities changes in response to antibiotic exposure and that this type of disturbance increases the abundance of resistant bacteria (Liu et al. 2012). Nonetheless, a retrospective demonstration of a cause-and-effect relationship between antibiotic usage and tolerance development has never been tested under field conditions in the tropics, where the ecotoxicology of antibiotics may be unique due to biotic and abiotic factors and highly valued ecosystems, such as wetlands, rain forests, coral reefs, and 
57 rivers, are exposed to these compounds due to their proximity to agroecosystems. With this in 58 mind, and aiming to assess the nature and magnitude of physiological adaptations that OTC 59 exposure could have caused in tropical agroecosystems, we determined the in vitro level of 60 tolerance to OTC of sediment bacteria from 5 locations and a reference wetland located in 61 Northwestern Costa Rica. 


\section{Materials and methods}

\section{Description of the sites}

We studied sediment samples collected in February, May, August, and November 2009 at the drainage of the last of a series of three oxidation ponds collecting wastewater from a pig farm with 8000 animals (RD), a channel receiving effluents from numerous ponds in a tilapia farm of 210 ha (TIL2), the drainage of an artificial wetland used to treat wastewater in the same tilapia farm (TIL1), an estuary receiving wastewater from various shrimp farms (CA), an irrigation channel next to a rice plantation of approximately 300 ha (AZ), and a protected wetland in the Palo Verde National Park (PV). These sites are located in a tropical dry region in Northwestern Costa Rica that is irrigated with water from the Lake Arenal through a system of channels covering ca. $28000 \mathrm{Ha}$ (Arenal Tempisque Irrigation District; ATID). de la Cruz and collaborators (2014) recently estimated that $0.014-0.340 \mathrm{Kg} / \mathrm{Ha} /$ year, $0-1.93 \mathrm{Kg} / \mathrm{Ha} /$ year, and $0.82-107.3 \mathrm{Kg} / \mathrm{Ha} /$ year of OTC are consumed in agriculture, aquaculture, and swine production activities in the ATID, respectively.

\section{Sediment collection and analysis}

Three samples of approximately $6 \mathrm{~L}$ of sediment were collected with a shovel from the upper 30 $\mathrm{cm}$ of the horizon. These materials were transported to the laboratory on ice in plastic jars filled to their maximum capacity and covered with overlaying water. Once in the laboratory, samples were maintained at $4^{\circ} \mathrm{C}$ for a maximum of $24 \mathrm{~h}$ before analysis. The dissolved oxygen, $\mathrm{pH}$ value, temperature, and conductivity of overlaying water associated with the sediments were measured at the field with a portable multimeter (HQ11d, Hach, Loveland, CO, USA). This data, together with the organic carbon content (LOI $550^{\circ} \mathrm{C}$ ) and the texture of the sediments, appears in Table 1.

\section{Tetracycline screening by LC/MS/MS in water and sediment samples}

OTC, chlortetracycline (CTC), and tetracycline (TC) were determined in surface water samples with the protocol of Christian et al. (2003). Briefly, $500 \mathrm{ml}$ of water samples cleared through glass fibre filters $(\mathrm{GC} / \mathrm{C}$, Whatman, ø $47 \mathrm{~mm}, 1.2 \mathrm{~mm})$ and whose $\mathrm{pH}$ was adjusted to 4.0 with 2 $\mathrm{M} \mathrm{H}_{2} \mathrm{SO}_{4}$ were mixed with $1 \mathrm{~mL}$ of EDTA $200 \mathrm{mg} \mathrm{mL}^{-1}$ to prevent bonding of the analytes to glass. Thereafter, they were passed with a flow rate $<10 \mathrm{~mL} \mathrm{~min}^{-1}$ through SPE OASIS HLB cartridges (Waters $200 \mathrm{mg} / 6 \mathrm{~mL}$ ) that were conditioned with $6 \mathrm{~mL}$ of methanol and $6 \mathrm{~mL}$ of ultrapure water $\left(18.2 \mathrm{M} \Omega \mathrm{cm}^{-1}\right)$. The SPE cartridges were dried by centrifugation for $2 \mathrm{~min}$ at 
$5000 \mathrm{rpm}$ and then by vacuum during $10 \mathrm{~min}$, and the analytes were eluted with $5 \mathrm{~mL}$ of methanol. The extracts were concentrated to approximately $0.05 \mathrm{~mL}$ in a water bath at $35^{\circ} \mathrm{C}$ under a gentle nitrogen flow and redissolved in $0.8 \mathrm{~mL}$ of a mixture of water:acetonitrile (9:1, $\mathrm{V} / \mathrm{V}$ ) applying ultrasonic bath for $1 \mathrm{~min}$. Extracts were filtered through a $0.45 \mu \mathrm{m}$ membrane filter and transferred to polypropylene injection vials. Blank samples of ultrapure water (18.2 $\mathrm{M} \Omega$ $\mathrm{cm}^{-1}$ ) were run to control for possible contamination of the analytical procedure. Sediment samples were processed by liquid extraction with a method described by Hamscher et al. (2002). In this procedure, sediments were homogenized using a $1 \mathrm{~mm}$ sieve, their excess water was drained, and tubes and glassware were washed with water and methanol, heated at $400{ }^{\circ} \mathrm{C}$ for $1 \mathrm{~h}$, and rinsed with a saturated methanolic solution of EDTA prior to extraction to avoid losses due to association of the analytes with organic matter and divalent cations. One $g$ of each sediment was homogenized with $1 \mathrm{~mL}$ of $1 \mathrm{M}$ citrate buffer solution ( $\mathrm{pH} 4.7$ ) using a vortex. Thereafter, $6 \mathrm{ml}$ of ethyl acetate were added to the suspensions and they were shaken for 15 minutes prior to centrifugation for 10 minutes at $1000 \mathrm{x}$ g. The organic phase was recovered and the extraction procedure was repeated once. Pooled organic fractions were concentrated under a gentle flow of nitrogen and the residue was resolved in $1 \mathrm{~mL}$ of water/acetonitrile $(9: 1 \mathrm{~V} / \mathrm{V})$. These concentrated extracts were filtered through $0.45 \mu \mathrm{m}$ membranes and transferred to polypropylene injection vials. Every sediment sample was extracted in duplicate. For both water and sediment extracts, analyte separation and detection was achieved by LC-MS/MS using a triple quadrupole mass analyser (4000 QTrap, Applied Biosystems/MDS SCIEX) with electrospray ionization (ESI) connected to a Shimadzu HPLC system and operated in the positive ion mode. The samples were injected on a ACE column $(5 \mu \mathrm{m}, \mathrm{C} 18,150 \times 3 \mathrm{~mm}$; Advanced Chromatography Technologies, Aberdeen, UK) at $30^{\circ} \mathrm{C}$. As mobile phase we used (A) $1 \mathrm{mM}$ ammonium acetate buffer in subboiled water and methanol (ULC/MS grade Biosolve) (95/5 V/V) and (B) $1 \mathrm{mM}$ ammonium acetate buffer in sub-boiled water and methanol $(5 / 95 \mathrm{~V} / \mathrm{V})$, both containing $0.1 \%$ formic acid $(\mathrm{V} / \mathrm{V})$. The total flow rate of eluent $\mathrm{A}$ and $\mathrm{B}$ was $0.4 \mathrm{~mL} \mathrm{m^{-1 }}$. The gradient program was: $80 \% \mathrm{~A}$ (2 min), $70 \% \mathrm{~A}(9 \mathrm{~min}), 10 \% \mathrm{~A}(13-19 \mathrm{~min})$ and finally $80 \% \mathrm{~A}$. The total run time was $21 \mathrm{~min}$.

\section{Determination of CLPP and calculation of OTC-induced community tolerance} Bacteria were extracted from the sediments with the methods of Burke et al. (2002) and Schmitt et al. (2004). Briefly, suspensions prepared with $10 \mathrm{~g}$ of solid matter from the sediments and 40 $\mathrm{mL}$ of $0.1 \%$ sodium pyrophosphate were shaken for $2 \mathrm{~min}$ by hand and homogenized 5 times by means of sonication for 10 seconds at $47 \mathrm{kHz}$. Thereafter, soil particles were separated from bacteria by centrifugation at $500 \mathrm{x} g$ for $15 \mathrm{~min}$ and the supernatants were immediately frozen in 
liquid $\mathrm{N}_{2}$. Each extraction was performed by triplicate and the extracts were stored at $-70^{\circ} \mathrm{C}$ for not more than 6 days. Extracted bacteria were exposed to $0.1,1,3,6,10,25,50$, and $100 \mathrm{mg} \mathrm{L}^{-1}$ of OTC $\mathrm{HCl}$ (Sigma) in EcoPlates ${ }^{\circledR}\left(\right.$ Biolog $^{\circledR}$ ) that were incubated for 6 days at $25^{\circ} \mathrm{C}$ and $85 \%$ relative humidity in the dark. These plates contain 31 carbon sources representing amines, aminoacids, carbohydrates, carboxylic acids, phenolic compounds, and polymers. The Ecoplates ${ }^{\circledR}$ were incubated for a long period of time to appraise the contribution of slow growing bacteria. The utility of the range of OTC concentrations assayed to reveal effects of low, medium, and strong magnitude was verified in preliminary experiments. Moreover, we followed the dilutionbased method recommended of Schmitt et al. (2004) to ensure that equal amounts of bacteria were added to the plates. Daily absorbance measurements of plate wells at $595 \mathrm{~nm}$ were transformed into WCD (standardized well color development) or AWCD (average well color development) values and thereafter into AUC values (area under the curve). This data treatment was favored because AUC, unlike AWCD and WCD, contemplate irregularities in color formation across time and provide a more comprehensive view of respiration kinetics. To express OTC effects in a relative scale, normalized AUC (nAUC) were calculated by dividing the AUC of plates containing OTC by the AUC of control plates without OTC. Finally, nAUC were exploited to calculate logistic dose-response curves from which the concentration of OTC needed to reduce color formation in 50\% (Effect Concentration 50\%; $\mathrm{EC}_{50}$ ) was estimated with the formula: $\mathrm{Y}=$ Bottom $+($ Top-Bottom $) /\left(1+10^{\wedge}\left(\left(\mathrm{X}-\log \mathrm{EC}_{50}\right)\right)\right)($ Hill slope=-1.0). Curve fitting was considered appropriate if a non-lineal regression exhibited $\mathrm{a}^{2} \geq 0.3$ and the logarithm of the standard error of the $\mathrm{EC}_{50}$ was $<1$ (Schmitt et al. 2004; Schmitt et al. 2005; Kamitani et al. 2006).

\section{Plate counts of OTC-resistant bacteria}

Serial dilutions of sediment suspensions in $0.8 \%$ saline solution were inoculated by triplicate onto trypticase soy agar plates (TSA, Oxoid) supplemented with 1, 10, or $100 \mu \mathrm{g} \mathrm{mL} \mathrm{L}^{-1}$ of OTC. All plates included $50 \mu \mathrm{g} \mathrm{mL}^{-1}$ of cycloheximide to inhibit the growth of mycelial fungi and $2 \%$ of agar to limit bacterial swarming. Plate counts were recorded after incubation for $120 \mathrm{~h}$ at $30^{\circ} \mathrm{C}$ under aerobiosis.

\section{Statistical analyses}

nAUC and $\mathrm{EC}_{50}$ values, as well as plate counts, were compared by means of analyses of variance (ANOVA) or appropriate non-parametrical tests at a 0.05 level of significance. All differences were corroborated with Post-Hoc tests. Linear models were calculated to determine the influence 
of several physicochemical characteristics of the sediments (PCS) on the development of microbial tolerance to OTC. When required, PCS were log transformed to obtain normal distributions. Plots depicting cumulative distributions of individual $\mathrm{EC}_{50}$ values were also prepared to assess OTC tolerance across the range of concentrations and carbon sources tested.

\section{Results}

\section{LC/MS/MS screening of tetracyclines}

OTC was the only tetracycline detected in our survey of environmental samples (Table 2). More water than sediment samples rendered positive results and, without exception, concentrations were in the order of $\mathrm{ng} \mathrm{L}^{-1}$ and $\mathrm{ng} \mathrm{g}^{-1}$, respectively (Table 2). OTC was detected in all samples collected at the fish farm (TIL1 and TIL2). However, higher amounts were found in the pig farm (RD). While rather low concentrations were detected in samples from CA, no tetracyclines were detected in $\mathrm{AZ}$ or in $\mathrm{PV}$.

\section{Carbon source respiration}

Sigmoid curves typified the respiration of the carbon sources analyzed. Variations in the initial response times, curve slopes, and the time elapsed until respiration ceased, were observed across the samples. In general, nAUC diminished in proportion to the concentration of OTC added to the plates. However, a few communities showed increased catabolic activities in presence of $0.1 \mathrm{mg}$ $\mathrm{L}^{-1}$ of OTC or an OTC-dependent stimulation of respiration in some substrates (Fig. S1). When nAUC from all substrates and OTC concentrations were averaged, the microbial community from RD showed higher values $(5.27 \pm 0.11)$ than bacteria from TIL1 $(3.59 \pm 0.08)$, TIL2 $(2.76 \pm$ $0.07), \mathrm{CA}(2.73 \pm 0.08), \mathrm{AZ}(2.87 \pm 0.10)$, and PV $(2.85 \pm 0.07)$ (Fig. $1 ; \mathrm{p}<0.05)$. A two-way ANOVA evidenced highly significant differences in bacterial respiration across OTC concentrations $(\mathrm{F}=265.0, \mathrm{p}<0.0001)$. Moreover, a subsequent ANOVA test at fixed OTC concentrations confirmed that RD had higher respiration values than all other sites at OTC concentrations above $1 \mathrm{mg} \mathrm{L}^{-1}$. This predominance of RD can also be graphically seen in Figure S2.

\section{OTC tolerance}

A total of 369 dose-response curves showing inhibition were considered in the calculation of $\mathrm{EC}_{50}$. Most of these inhibitory curves were documented in wells containing carbohydrates 
( $n=130)$, aminoacids ( $n=82)$, or carboxylic acids $(n=76)$. RD gave rise to the highest average OTC tolerance values for 4 of the 6 types of carbon sources assayed (Table 3). While bacteria from $\mathrm{AZ}$ and $\mathrm{CA}$ had comparable or higher $\mathrm{EC}_{50}$ for phenolic compounds and polymers than bacteria from $\mathrm{RD}$, all other sites showed lower individual and average $\mathrm{EC}_{50}$ than $\mathrm{RD}$ (Table 3). The average OTC tolerance of RD $\left(14.30 \pm 3.12 \mathrm{mg} \mathrm{L}^{-1}\right)$ was significantly higher than that of TIL1 $\left(4.25 \pm 0.60 \mathrm{mg} \mathrm{L}^{-1}\right)$, TIL2 $\left(4.97 \pm 1.43 \mathrm{mg} \mathrm{L}^{-1}\right), \mathrm{CA}\left(8.83 \pm 1.85 \mathrm{mg} \mathrm{L}^{-1}\right), \mathrm{AZ}(3.66 \pm 0.97$ $\left.\mathrm{mg} \mathrm{L}^{-1}\right)$, and PV $\left(3.77 \pm 0.62 \mathrm{mg} \mathrm{L}^{-1}\right)(\mathrm{p}=0.0001)$. However, a cumulative distribution of individual $\mathrm{EC}_{50}$ revealed a right-skewed behavior of tolerance, with reference wetland $\mathrm{PV}$ at the far left, AZ and TIL1 followed by CA and TIL2 in the middle, and RD in the far right (Fig. 2). This trend was more apparent at higher OTC concentrations.

Linear models calculated with the physicochemical parameters included in Table 1 revealed that Clay $(\mathrm{F}=7.19, P=0.01$; Pearson correlation=-0.49) and to a lesser extent log transformed Sand $\left(\mathrm{F}=4.42, P=0.047\right.$, Pearson correlation=0.409) explained the OTC tolerance and elevated $\mathrm{EC}_{50}$ recorded for RD. Furthermore, a linear regression model of $\mathrm{EC}_{50}$ created by a forward stepwise regression assigned the highest predictive values to suspended solids, silt and clay in combination (data not shown).

\section{Plate counts of OTC-resistant bacteria}

Culturable bacteria resistant to 1,10 , or $100 \mu \mathrm{g} \mathrm{mL}^{-1}$ of OTC were found in all sites. Counts of bacteria resistant to $1 \mu \mathrm{g} \mathrm{mL} \mathrm{m}^{-1}$ of OTC were comparable across the sites. By contrast, bacteria from PV, AZ, CA, TIL1 and TIL2 were more severely inhibited by $10 \mu \mathrm{g} \mathrm{L}^{-1}$ and $100 \mu \mathrm{g} \mathrm{L}^{-1}$ of OTC than bacteria from RD (Fig. 3). In detail, the abundance of OTC-resistant bacteria in RD (10 $\left.\mu \mathrm{g} \mathrm{mL} \mathrm{m}^{-1}: 5.00 \times 10^{5}-1.50 \times 10^{7} ; 100 \mu \mathrm{g} \mathrm{mL}^{-1}: 1.50 \times 10^{4}-8.40 \times 10^{5}\right)$ was one or two orders of magnitude higher than that recorded for all other sites $\left(10 \mu \mathrm{g} \mathrm{mL}^{-1}: 4.83 \times 10^{4}-3.33 \times 10^{5} ; 100 \mu \mathrm{g}\right.$ $\left.\mathrm{mL}^{-1}: 1.00 \times 10^{2}-4.37 \times 10^{3}\right)$.

\section{Discussion}

The pollution-induced community tolerance (PICT) concept postulates that exposition of a community to a contaminant will result in increased tolerance of its members against the xenobiotic compound. This concept is applicable to microorganisms (van Beelen et al. 2001; van Beelen 2003) and allows for evaluation of toxic effects in a short period of time without ignoring the role of biological interactions (Segner 2007). Others have used PICT to study the impact of 
215 metals such as Zn, Cu, Pb and Cd (Pennanen et al. 1996; Díaz-Raviña and Bååth 1996; Díaz-

216 Raviña 1994; Bååth 2005) and antibiotics such as sulfonamide (Schmitt et al. 2004) on the

217 functioning of communities of environmental bacteria. We exploited it to assess the nature and

218 magnitude of the physiological adaptations triggered by a widely used antibiotic in tropical

219 sediments from diverse locations.

220 The respiration of most carbon sources and the concentration of OTC added to the wells of the

221 Ecoplates $^{\circledR}$ were inversely related. This dose-dependent inhibition was consistent across the

222 samplings and sustained notwithstanding that the time elapsed between the last in situ exposure

223 of the sediments to antibiotics to OTC and their de novo exposition to this compound in the

224 laboratory is unknown. We therefore conclude that the adaptations developed by the bacterial

225 communities assayed are stable.

226 The stimulation of the respiration of certain substrates in presence of $0.1 \mathrm{mg} \mathrm{l}^{-1}$ of OTC is an

227 example of hormesis; a phenomenon that has previously been reported for tobramycin,

228 tetracycline, and norfloxacin (Linares et al. 2006) and for OTC in a tropical soil (Solís et al.

229 2011). The interpretation of responses to such low concentrations of toxicants requires further

230 research; however, recent investigations demonstrate that natural concentrations of antibiotics

231 influence gene expression and intercellular communication at the community level (Yim et al.

232 2007; Fajardo and Martinez 2008). On the other hand, as pollutants may serve as carbon source

233 (Dantas et al. 2018) or stimulate nutrient release by pollutant degraders (Cycoń et al. 2006), it is

234 plausible that OTC-degraders contributed to the development of OTC tolerance. In this regard,

235 Liu et al. (2012) recently noted that chlortetracycline and sulfamethoxazole may serve as

236 nutrients for soil bacteria.

237 The sediment from RD and one of the sediments from the fish farm (TIL1) showed top

238 respiration rates. The clearest differentiation between sites was obtained with OTC concentrations

239 between 3 and $6 \mathrm{mg} \mathrm{l}^{-1}$, presumably because concentrations $>6 \mathrm{mg} \mathrm{l}^{-1}$ give rise to attenuated

240 profiles that sacrifice relevant information and exposition to $<3 \mathrm{mg} \mathrm{l}^{-1}$ does not elicit detectable

241 phenotypic responses. On the other hand, the key contribution of the carbohydrates and the

242 aminoacids in the differentiation of bacterial communities seems to be related to more favorable

243 conditions for the growth of r-strategists over K-strategists under high-nutrient conditions

244 (Preston-Mafhamet al. 2002; Stefanowicz 2006). We recommend considering these

245 concentrations and carbon sources in the design of bioassays dealing with the ecotoxicology of

246 tetracyclines. 
The graph with cumulative $\mathrm{EC}_{50}$ showed that the community extracted from the protected area (PV) was, in comparison to the other communities studied, more sensitive to OTC. The communities of AZ, CA and TIL1 were characterized by intermediate $\mathrm{EC}_{50}$ values, whereas bacteria from one of the sites in the fish farms where OTC was commonly detected (TIL2), and from the swine farm illustrating higher antibiotic usage and containing greater amounts of OTC residues, were more tolerant to OTC. Thus, our data indicates a scenario where a basal level of natural tolerance to OTC becomes amplified in line with the intensity of antibiotic usage in agriculture. This interpretation is supported by the OTC consumption figures presented in the Materials \& Methods section.

The increased tolerance of the microbial community of RD was corroborated by the fact that it retained most catabolic functions at high OTC concentrations. Therefore, it is likely that OTC tolerance was developed in diverse bacterial groups. In future studies, microscopic and molecular analyses could be considered to identify key players and to estimate their individual contribution to the community phenotype.

In agreement with the notion that antibiotic resistance is a natural phenomenon (Martinez 2009), we found large numbers of OTC-resistant bacteria in pristine locations. However; their abundance and level of susceptibility was much lower than those of bacteria from humanimpacted sediments in farms. The growing antibiotic resistance of bacterial pathogens, along with the contamination of the environment and of foodstuff with antibiotics, antibiotic-resistant bacteria, and antibiotic-resistance genes, is a global concern from sanitary, economic, and ecological perspectives. In Costa Rica and in many other developing countries, pig manure is exploited as soil fertilizer or in cow nutrition and fishpond sediments are used to fertilize sugarcane plantations. Therefore, the OTC-resistant bacteria reported here can find a way out of the farms. This situation is particularly worrisome because resistant bacteria can persist in natural reservoirs in absence of obvious selective pressures (Miranda and Zemelman 2002) and also because biocides and other substances commonly used to disinfect farm facilities may co-select resistant bacteria (Sheldon 2005). This could explain why degraders of phenolic compounds and polymers from $\mathrm{AZ}$ and $\mathrm{CA}$ and from $\mathrm{RD}$ exhibited similar OTC tolerances. It is known that abiotic factors can shape tolerance through interactions with pollutants. For example, Boivin et al (2005) reported an effect of temperature on the magnitude of cooperinduced tolerance in aquatic microbial communities, probably due to exposure enhancement. Among other factors, the concentration of organic matter (Doi and Stoskof 2000), clay (Chang et al. 2009), oxygen, divalent metals (MacKay and Canterbury 2005), and degrading bacteria in the 
matrix, has been shown to influence the fate and activity of OTC in the environment and thereby the exposure that microbial communities may encounter. In our study, the low percentage of clay in the sediment from RD is a likely explanation for the elevated OTC tolerance of its bacterial community. An additional non-excluding reason for the high tolerance recorded for RD is the massive and intensive use of $\beta$-lactams, sulfonamides, and tetracyclines in pig farming (Sarmah et al. 2006); a situation that was also confirmed in RD (de la Cruz et al. 2014).

Overall, our PICT findings provide more clear-cut indications than studies addressing the relationship between antibiotic consumption and resistance development. For instance, the Danish Integrated Antimicrobial Resistance Monitoring and Research Programme -a surveillance and research programme for antibiotic consumption and resistance in bacteria from animals, food and humans- concluded that the occurrence of tetracycline resistance in Danish pig production rises steadily even though tetracycline use has decreased over the last two years, and that resistance to vancomycin and quinupristin/dalfopristin persists at low levels among Enterococcus faecium isolates from pigs despite of the ban of avoparcin and virginiamycin called more than ten years ago (DANMAP 2010). Given that tolerance development to antibiotics reflects real selection pressures rather than multidrug resistance patterns and that PICT experiments in controlled microcosms and ecotoxicological test systems of equivalent complexity deliver comparable results (Schmitt et al. 2009), PICT investigations may find an application in environmental impact assessments on the field. In this respect, our data strongly postulate intermediate concentrations of OTC as valuable markers of antibiotic exposure.

\section{Conclusions}

Our study shows a causal relationship between antibiotic exposure and OTC tolerance development in tropical sediments. To the best of our knowledge, this is the first report of an antibiotic PICT experiment in tropical and/or subtropical areas, where most studies in aquaculture farms and aquaculture-impacted environments have aimed to inventory antibiotic resistant bacteria and antibiotic resistance genes (Su et al. 2011; Thuy et al. 2011) in full disregard of the contribution of environmental variables to the results. Our results were interpreted in function of the physicochemical characteristics of the sediments analyzed and, in opposition to most investigations for Europe and USA (Schmitt et al 2004; Brandt et al. 2009; Demoling et al. 2009), tolerance profiles were obtained for microbial ensembles subjected to different exposure regimes at the field. 
311 Developing countries like Costa Rica have consistently and traditionally showed difficulties in

312 the regulation of pesticides and the implementation of good agricultural practices (Castillo et al.

313 2006), residual water treatment (OPS 2003), and according to our experience and appreciation, in

314 the overall management of antibiotics in medicine and farming (Gutiérrez et al 2010; Granados et

315 al. 2012). Our results support the latter observation and nourish the limited knowledge on the

316 ecotoxicology of antibiotics in aquatic ecosystems (Ding and He 2010). Furthermore, since

317 diversity losses lead to higher ecosystem vulnerability (Girvan et al. 2005; Szabó et al. 2007) and

318 macromolecular carbon degraders are critical to ecosystem stability (Waldrop and Firestone

319 2004), our results justify the design and execution of monitoring programs of antibiotics and

320 antibiotic resistance and of robust risk assessments to increase the awareness of farmers and

321 consumers on the public and environmental health implications of antibiotic use in the tropics.

322 Acknowledgements The authors thank Heike Schmitt for her help with the setup and 323 interpretation of the PICT experiments and Frans van der Wielen (University of Amsterdam) for 324 his support with the LC/MS/MS analyses. 


\section{References}

Avisar D, Lester Y, Ronen D. 2009. Sulfamethoxazole contamination of a deep phreatic aquifer. Science of the Total Environment 407:4278-4282.

Bååth E, Díaz-Raviña M, Bakken LR. 2005. Microbial biomass, community structure and metal tolerance of a naturally Pb-enriched forest. Microbial Ecology 50:496-505.

Boivin M-E, Massieux B, Breure AM, van den Ende FP, Greve GD, Rutgers M, Admiraal W. 2005. Effects of copper and temperature on aquatic bacterial communities. Aquatic Toxicology 71(4):345-356.

Brandt KK, Sjøholm OR, Krogh KA, Halling-Sørensen B, Nybroe O. 2009. Increased pollutioninduced bacterial community tolerance to sulfadiazine in soil hotspots amended with artificial root exudates. Environmental Science \& Technology 43:2963-2698.

Burke DJ, Hamerlynck EP, Hahn D. 2002. Interactions among plant species and microorganisms in salt marsh sediments. Applied and Environmental Microbiology 68:1157-1163.

Carson M, Bullock G, Bebak-Williams J. 2002. Determination of oxytetracycline residues in matrixes from a freshwater recirculating aquaculture system. Journal of AOAC International 85:341-348.

Castillo LE, Martínez E, Ruepert C, Savage C, Gilek M, Pinnock M, Solis E. 2006. Water quality and macroinvertebrate community response following pesticide applications in a banana plantation, Limon, Costa Rica. Science of the Total Environment 367:418-432.

Chang PH, Li Z, Jiang WT, Jean JS. 2009. Adsorption and intercalation of tetracycline by swelling clay minerals. Applied Clay Science 46:27-36.

Christian, T., Schneider, R. J., Färber, H. A., Skutlarek, D., Meyer, M. T. and Goldbach, H. E. (2003) Determination of Antibiotic Residues in Manure, Soil, and Surface Waters. Acta Hydrochimica et Hydrobiologica 31: 36-44.

Cycoń M, Piotrowska-Seget Z, Kaczyńska A, Kozdrój J. 2006. Microbiological characteristics of a sandy loam soil exposed to tebuconazole and lambda-cyhalothrin under laboratory conditions. Ecotoxicology 15(8):639-646

DANMAP Report 2010. Use of antimicrobial agents and occurrence of antimicrobial resistance in bacteria from food animals, food and humans in Denmark. Report from the the Danish Integrated Antimicrobial Resistance Monitoring and Research Programme. ISSN 1600-2032 Available at http://www.danmap.org de la Cruz E, Fournier ML, García F, Molina A, Chavarría G, Alfaro M, Ramírez F, Rodríguez C. 
2014. Hazard prioritization and risk characterization of antibiotics in an irrigated tropical region used for intensive crop, livestock, and aquaculture farming. Journal of Environmental Biology 35: 85-98.

Demoling LA, Bääth E, Greve G, Wouterse M, Schmitt H. 2009. Effects of sulfamethoxazole on soil microbial communities after adding substrate. Soil Biology \& Biochemistry 41:840-848. Díaz-Raviña M, Bååth E, Frostegård Å. 1994. Multiple heavy metal tolerance of soil bacterial communities and its measurement by a thymidine incorporation technique. Applied and Environmental Microbiology 60:2238-2247.

Díaz-Raviña M, Bååth E. 1996. Development of metal tolerance in soil bacterial communities exposed to experimentally increased metal levels. Applied and Environmental Microbiology 62:2970-2977.

Ding, C, He J. 2010. Effect of antibiotics in the environment on microbial populations. Applied Microbiology and Biotechnology 87:925-941.

Doi AM, Stoskopf MK. 2000. The kinetics of oxytetracycline degradation in deionized water under varying temperature, $\mathrm{pH}$, light, substrate, and organic matter. Journal of Aquatic Animal Health 12:246-253.

Fajardo A, Martínez JL. 2008. Antibiotics as signals that trigger specific bacterial responses. Current Opinion in Microbiology 11:161-167.

Girvan MS, Campbell CD, Killham K, Prosser JI, Glover LA. 2005. Bacterial diversity promotes community stability and functional resilience after perturbation. Environmental Microbiology 7:301-313.

Granados F, Sánchez J, García F, Rodríguez C. 2012. A novel green chemistry method for nonaqueous extraction and HPLC detection of first-, second-, and third-generation tetracyclines, 4epitetracycline, and tylosin in animal feeds. Journal of Agricultural and Food Chemistry 60:7121-7128.

Gutiérrez K, Alfaro M, Granados F, Sánchez J, García F, Rodríguez C. 2010. Detección de tetraciclinas en nueve lotes de alimentos para cerdos, tilapias y pollos producidos en Costa Rica: incumplimiento de normativas y disconformidades con el etiquetado oficial de garantía. Agronomía Costarricense 34:145-151.

Hamscher G, Sczesny S, Höper H, Nau H. 2002. Determination of persistent tetracycline residues in soil fertilized with liquid manure by high-performance liquid chromatography with electrospray ionization tandem mass spectrometry. Analytical Chemistry 74(7):1509-18. 
Heberer T. 2002. Ocurrence, fate and removal of pharmaceutical residues in the aquatic environment: a review of research data. Toxicology Letters 131:5-17. Hernando MD, Mezcua M, Fernández-Alba AR, Barceló D. 2006. Environmental risk assessment of pharmaceutical residues in wastewater effluents, surface waters and sediments. Talanta 69: 334-342.

Kamitani TH, Oba H, Kaneko N. 2006. Microbial biomass and tolerance of microbial community on an aged heavy metal polluted floodplain in Japan. Water, Air, \& Soil Pollution 172:185-200. Kümmerer K. 2009. Antibiotics in the aquatic environment-A review-Part I. Chemosphere 75:417-434.

Lalumera GM, Calamari D, Galli P, Castiglioni S, Crosa G, Fanelli R. 2004. Preliminary investigation on the environmental occurrence and effects of antibiotics used in aquaculture in Italy. Chemosphere 54: 661-668.

Li Z-J, Xie, X-Y, Zhang S-Q, Liang Y-C. 2011. Wheat growth and photosynthesis as affected by oxytetracycline as a soil contaminant. Pedosphere 21(2)244-250.

Linares JF, Gustafsson I, Baquero F, Martinez JL. 2006. Antibiotics as intermicrobial signaling agents instead of weapons. Proceedings of the National Academy of Sciences 103:19484-19489. Liu W, Pan N, Chen W, Jiao W, Wang M. 2012. Effect of veterinary oxytetracycline on functional diversity of soil microbial community. Plant Soil and Environment 58(7):295-301.

Lunestad BT, Goksøyr J. 1990. Reduction in the antibacterial effect of oxytetracycline in sea water by complex formation with magnesium and calcium. Diseases of Aquatic Organisms 9:6772 .

MacKay AA, Canterbury B. 2005. Oxytetracycline sorption to organic matter by metal-bridging. Journal of Environmental Quality 34:1964-1971.

Maki T, Hasegawa H, Kitami H, Fumoto K, Munekage Y, Ueda K. 2006. Bacterial degradation of antibiotic residues in marine fish farm sediments of Uranouchi Bay and phylogenetic analysis of antibiotic-degrading bacteria using 16S rDNA sequences. Fisheries Science 72:811-820. Martinez JL. 2009. The role of natural environments in the evolution of resistance traits in pathogenic bacteria. Proceedings of the Royal Society B 276: 2521-2530.

Miranda CD, Zemelman R. 2002. Bacterial resistance to oxytetracycline in Chilean salmon farming. Aquaculture 212:31-47.

OPS. 2003. Calidad del agua potable en Costa Rica: Situación actual y perspectivas. Organización Panamericana de la Salud, Ministerio de Salud. San José, Costa Rica. 40 p. (Serie Análisis de Situación de Salud; no. 13) 
Park S, Choi K. 2008. Hazard assessment of commonly used agricultural antibiotics on aquatic ecosystems. Ecotoxicology 17:526-38.

Pennanen T, Frostegård Å, Fritze H, Bååth E. 1996. Phospholipid fatty acid composition and heavy metal tolerance of soil microbial communities along two heavy metal-polluted gradients in coniferous forests. Applied and Environmental Microbiology 62: 420-428.

Pijpers A, Schoevers EJ, Haagsma N, Verheijden JH. 1991. Plasma levels of oxytetracycline, doxycycline, and minocycline in pigs after oral administration in feed. Journal of Animal Science 69:4512-4522.

Piotrowska-Seget Z, Engel R, Nowak E, Kozdrój J. 2008. Successive soil treatment with captan or oxytetracycline affects non-target microorganisms. World Journal of Microbiology and Biotechnology 24:2843-2848.

Preston-Mafham J, Boddy L, Randerson PF. 2002. Analysis of microbial community functional diversity using sole-carbon-source utilization profiles e a critique. FEMS Microbiology Ecology 42:1-14.

Rodríguez C, Lang L, Wang A, Altendorf K, García F, Lipski A. 2006. Lettuce for human consumption collected in Costa Rica contains complex communities of culturable oxytetracycline and gentamicin-resistant bacteria. Applied and Environmental Microbiology 72:5870-5876.

Rodríguez C, Altendorf K, Smalla K, Lipski A. 2007. Spraying of oxitetracycline and gentamicin onto field-grown coriander did not affect the abundance of resistant bacteria, resistance genes, and broad host range plasmids detected in soil bacteria from a Costa Rican farm. Biology and Fertility of Soils 44:589-596.

Rodríguez C. 2008. Oxytetracycline and gentamicin: two clinically-relevant antimicrobials widely used by Costa Rican farmers. Revista Medica de la Universidad de Costa Rica. 2(2) Available at: http://www.latindex.ucr.ac.cr/med004-06.php

Rubert KF, Pedersen JA. 2006. Kinetics of oxytetracycline reaction with a hydrous manganese oxide. Environmental Science \& Technology 40:7216-7221.

Sarmah AK, Meyer MT, Boxall ABA. 2006. A global perspective on the use, sales, exposure pathways, occurrence, fate and effects of veterinary antibiotics (VAs) in the environment. Chemosphere. 65:725-759.

Schmitt H, van Beelen P, Tolls J, van Leeuwen CL. 2004. Pollution-induced community tolerance of soil microbial communities caused by the antibiotic sulfachloropyridazine. Environmental Science \& Technology 38:1148-1153. 
Schmitt H, Haapakangas H, van Beelen P. 2005. Effects of antibiotics on soil microorganisms: time and nutrients influence pollution-induced community tolerance. Soil Biology \& Biochemistry 37: 1882-1892.

Schmitt H, Martinali B, van Beelen P, Seinen W. 2006. On the limits of toxicant-induced tolerance testing: Cotolerance and response variation of antibiotic effects. Environmental Toxicology \& Chemistry 25:1961-1968.

Segner H. 2007. Ecotoxicology - how to assess the impact of toxicants in a multi-factorial environment? In: Mothersill C, Mosse I, Seymour C, eds. Multiple Stressors: A Challenge for the Future (NATO Science for Peace and Security Series C: Environmental Security), Neatherlands: Springer, 39-56.

Seyfried EE, Newton RJ, KF Rubert, Pedersen JA, McMahon KD. 2010. Occurrence of tetracycline resistance genes in aquaculture facilities with varying use of oxytetracycline. Microbial Ecology 59:799-807.

Sheldon AT. 2005. Antiseptic "resistance": real or perceived threat? Clinical Infectious Diseases 40:1650-1656.

Solís Y, Chavarría G, García F, Rodríguez C. 2011. Exposure of a tropical soil to $\mathrm{mg} / \mathrm{Kg}$ of oxytetracycline elicits hormetic responses in the catabolic activities of its microbial community. Dose Response 9:434-441.

Rodriguez Spongberg AL, Witter JD, Acuña J, Vargas J, Murillo M, Umaña G, Gómez E, Perez G. 2011. Reconnaissance of selected PPCP compounds in Costa Rican surface waters. Water Research 45:6709-6717.

Stefanowicz A. 2006. The Biolog plates technique as a tool in ecological studies of microbial communities. Polish Journal of Environmental Studies 15: 669-676.

Su HC, Ying GG, Tao R, Zhang RQ, Fogarty LR, Kolpin DW. 2011. Occurrence of antibiotic resistance and characterization of resistance genes and integrons in Enterobacteriaceae isolated from integrated fish farms in South China. Journal of Environmental Monitoring 13:3229-3236. Szabó KÉ, Itor POB, Bertilsson S, Tranvik L, Eiler A. 2007. Importance of rare and abundant populations for the structure and functional potential of freshwater bacterial communities. Aquatic Microbial Ecology 47:1-10.

Thuy HT, Nga le P, Loan TT. 2011. Antibiotic contaminants in coastal wetlands from Vietnamese shrimp farming. Environmental Science and Pollution Research 18:835-41. 
485 van Beelen P, Fleuren-Kemilä AK, Aldenberg T. 2001. The relation between extrapolated risk, 486 expressed as potentially affected fraction, and community effects, expressed as pollution induced 487 community tolerance. Environmental Toxicology \& Chemistry 20:1113-1140.

488 van Beelen, P. 2003. A review on the application of microbial toxicity tests for deriving sediment 489 quality guidelines. Chemosphere 53:795-808.

490 Waldrop MP, Firestone MK. 2004. Microbial community utilization of recalcitrant and simple 491 carbon compounds: impact of oak-woodland plant communities. Oecologia 138:275-284.

492 Yim G, Huimi Wang H, Davies J. 2007. Antibiotics as signalling molecules. Philosophical 493 Transactions of the Royal Society B: Biological Sciences 362:1195-1200. 


\section{Table 1 (on next page)}

Table 1. Site and sediment description. 


\begin{tabular}{lcccccc}
\hline & & \multicolumn{5}{c}{ Site $^{\mathrm{a}}$} \\
\hline Characteristic & PV & AZ & CA & TIL2 & TIL1 & RD \\
\hline & Dry & & & & & \\
tropical & & & & & \\
fite Vegetation & $\begin{array}{c}\text { Mangrove } \\
\text { covered } \\
\text { with } \\
\text { aquatic } \\
\text { plants }\end{array}$ & Open & Forest & Open & Open & Open \\
& & & & & \\
& & & & &
\end{tabular}

Overlaying Water

\begin{tabular}{|c|c|c|c|c|c|c|}
\hline $\mathrm{pH}$ & $7.0 \pm 0.3$ & $6.7 \pm 0.4$ & $7.1 \pm 0.05$ & $6.2 \pm 0.5$ & $5.8 \pm 0.3$ & $7.3 \pm 0.9$ \\
\hline $\begin{array}{l}\text { Conductivity } \\
\left(\mu \mathrm{S} \mathrm{cm}^{-1}\right)\end{array}$ & $1743 \pm 748$ & $587 \pm 261$ & $18233 \pm 6529$ & $115 \pm 4$ & $110 \pm 7$ & $5933 \pm 332$ \\
\hline $\begin{array}{c}\text { Dissolved } \\
\text { oxygen } \\
\left(\mathrm{mg} \mathrm{L}^{-1}\right)\end{array}$ & $3.9 \pm 0.7$ & $6.2 \pm 0.7$ & $5.3 \pm 0.5$ & $6.4 \pm 0.6$ & $3.5 \pm 0.9$ & $3.7 \pm 0.5$ \\
\hline $\begin{array}{l}\text { Total soluble } \\
\text { solids }\left(\mathrm{mg} \mathrm{L}^{-1}\right)\end{array}$ & $244 \pm 206$ & $517 \pm 408$ & $360 \pm 180$ & $35 \pm 18$ & $35 \pm 18$ & $253 \pm 11$ \\
\hline \multicolumn{7}{|c|}{ Sediment (\% dry weight) } \\
\hline Organic Matter & $8.8 \pm 0.8$ & $6.5 \pm 1.8$ & $10.4 \pm 0.5$ & $8.3 \pm 0.3$ & $9.2 \pm 0.4$ & $12.1 \pm 1.3$ \\
\hline Sand & $32.8 \pm 4.3$ & $50 \pm 5.8$ & $18.5 \pm 7.2$ & $28.0 \pm 4.6$ & $20.0 \pm 4.8$ & $66.3 \pm 11.6$ \\
\hline Silt & $23.8 \pm 1.1$ & $18.8 \pm 2.2$ & $32.3 \pm 3.1$ & $20.8 \pm 1.6$ & $20.0 \pm 1.9$ & $22.3 \pm 10.5$ \\
\hline Clay & $44.0 \pm 3.8$ & $31.3 \pm 3.8$ & $49.3 \pm 9.9$ & $51.3 \pm 4.5$ & $60.0 \pm 6.3$ & $11.8 \pm 1.3$ \\
\hline
\end{tabular}

${ }^{a} \mathrm{PV}=$ Palo Verde (reference wetland); $\mathrm{CA}=$ estuary close to shrimp farms; $\mathrm{AZ}=$ irrigation channel adjacent to a rice plantation; $\mathrm{TIL} 2=$ untreated effluent inside tilapia farm; $\mathrm{TIL} 1=$ treated effluent from tilapia farm; $\mathrm{RD}=$ oxidation lagoon in swine farm. Values represent mean $\pm \mathrm{SD}$. 


\section{Table 2 (on next page)}

Table 2. Results of a LC-MS/MS residue analysis of tetracyclines in water and sediment samples collected at 4 agroecosystems and a reference wetland. 
Site $^{\mathrm{a}}$

\begin{tabular}{|c|c|c|c|c|c|c|}
\hline & PV & $\mathrm{AZ}$ & $\mathrm{CA}$ & TIL2 & TIL1 & $\mathrm{RD}$ \\
\hline $\begin{array}{c}\text { Sampling } \\
\text { period }\end{array}$ & \multicolumn{6}{|c|}{ Water samples $\left(\mathrm{ng} \mathrm{L}^{-1}\right)^{\mathrm{b}}$} \\
\hline February & n.d. & n.d. & n.d & OTC $(t)$ & $\begin{array}{l}\text { OTC } \\
(12)\end{array}$ & n.d \\
\hline May & n.d. & n.d. & n.d. & $\begin{array}{r}\text { OTC } \\
(249)\end{array}$ & $\begin{array}{l}\text { OTC } \\
(43)\end{array}$ & n.d \\
\hline August & n.d. & n.d. & n.d. & OTC (89) & $\begin{array}{l}\text { OTC } \\
(33)\end{array}$ & OTC (462) \\
\hline \multirow[t]{2}{*}{ November } & n.d. & n.d. & $\begin{array}{l}\text { OTC } \\
(26)\end{array}$ & OTC (26) & $\begin{array}{l}\text { OTC } \\
(72)\end{array}$ & OTC (640) \\
\hline & \multicolumn{6}{|c|}{ Sediment samples $\left(\text { ng g }^{-1}\right)^{\mathrm{b}}$} \\
\hline February & n.d. & n.d. & $\mathrm{OTC}(t)$ & n.d. & n.d. & n.d \\
\hline May & n.d. & n.d. & n.d. & n.d. & n.d. & n.d \\
\hline August & n.d. & n.d. & n.d. & n.d. & n.d. & n.d \\
\hline November & n.d. & n.d. & n.d. & OTC $(t)$ & $\mathrm{OTC}(t)$ & n.d \\
\hline
\end{tabular}

${ }^{\text {apV}}=$ Palo Verde (reference wetland); $\mathrm{CA}=$ estuary close to shrimp farms; $\mathrm{AZ}=$ irrigation channel adjacent to a rice plantation; TIL2 $=$ untreated effluent inside tilapia farm; TIL1= treated effluent from tilapia farm; $\mathrm{RD}=$ oxidation lagoon in swine farm

${ }^{\mathrm{b}} \mathrm{OTC}=$ oxytetracycline; $t=$ traces; n.d. $=$ non detected 


\section{Table 3 (on next page)}

Table 3. Tolerance to OTC of sediment bacterial communities from 4 agroecosystems and a reference wetland. 
OTC tolerance $\left(\mathrm{EC}_{50} ; \mathrm{mg} \mathrm{L}^{-1}\right)$

\begin{tabular}{|c|c|c|c|c|c|c|c|}
\hline \multirow{3}{*}{ Site $^{\mathrm{a}}$} & & \multirow[b]{2}{*}{$\begin{array}{l}\text { Average EC } \mathrm{E}_{50} \\
\left(\mathrm{mg} \mathrm{L}^{-1}\right)\end{array}$} \\
\hline & \multicolumn{6}{|c|}{ Type of carbon source assayed ${ }^{\mathrm{b}, \mathrm{c}}$} & \\
\hline & A & AA & $\mathrm{C}$ & $\mathrm{CA}$ & $\mathrm{P}$ & $\mathrm{PC}$ & \\
\hline PV & 2.38 & 1.49 & 5.69 & 4.01 & 3.27 & 1.67 & $3.77 \pm 0.62$ \\
\hline $\mathrm{AZ}$ & 0.13 & 3.67 & 1.92 & 4.30 & 10.61 & 7.27 & $3.66 \pm 0.97$ \\
\hline $\mathrm{CA}$ & 14.18 & 5.51 & 7.11 & 5.31 & 21.35 & ND & $8.83 \pm 1.85$ \\
\hline TIL2 & 1.76 & 8.93 & 4.90 & 4.37 & 2.32 & 1.12 & $4.97 \pm 1.43$ \\
\hline TIL1 & 1.45 & 3.87 & 6.49 & 3.06 & 2.56 & 2.69 & $4.25 \pm 0.60$ \\
\hline $\mathrm{RD}$ & 16.92 & 14.66 & 20.53 & 9.53 & 9.70 & 7.60 & $14.30 \pm 3.12$ \\
\hline
\end{tabular}

${ }^{\text {aPV}}=$ Palo Verde (reference wetland); $\mathrm{CA}=$ estuary close to shrimp farms; $\mathrm{AZ}=$ irrigation channel adjacent to a rice plantation; $\mathrm{TIL} 2=$ untreated effluent inside tilapia farm; $\mathrm{TIL} 1=$ treated effluent from tilapia farm; $\mathrm{RD}=$ oxidation lagoon in swine farm ${ }^{\mathrm{b}} \mathrm{A}$ : amines; AA: aminoacids; C: carbohydrates; CA: carboxylic acids; P: polymers; PC: phenolic compounds

${ }^{\mathrm{C}}$ The highest $\mathrm{EC}_{50}$ for each type of carbon source assayed appears in bold 


\section{Figure 1}

Figure 1.

Average catabolic activity of sediment bacterial communities from agroecosystems and a protected wetland upon exposure to a range of OTC concentrations.

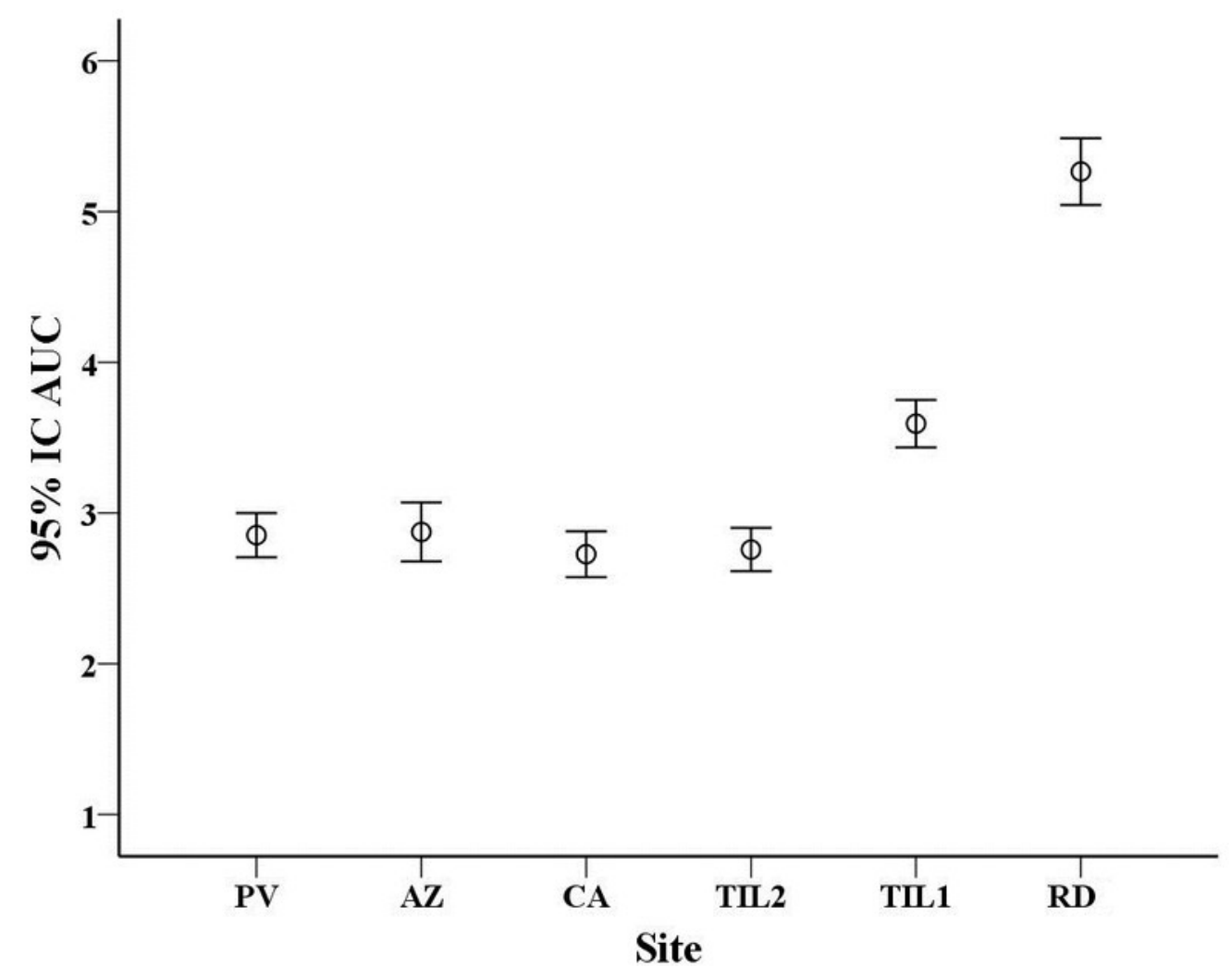




\section{Figure 2}

Figure 2.

Cumulative distribution of $\mathrm{EC}_{50}$ of OTC for sediment bacterial communities from agroecosystems and a protected wetland.

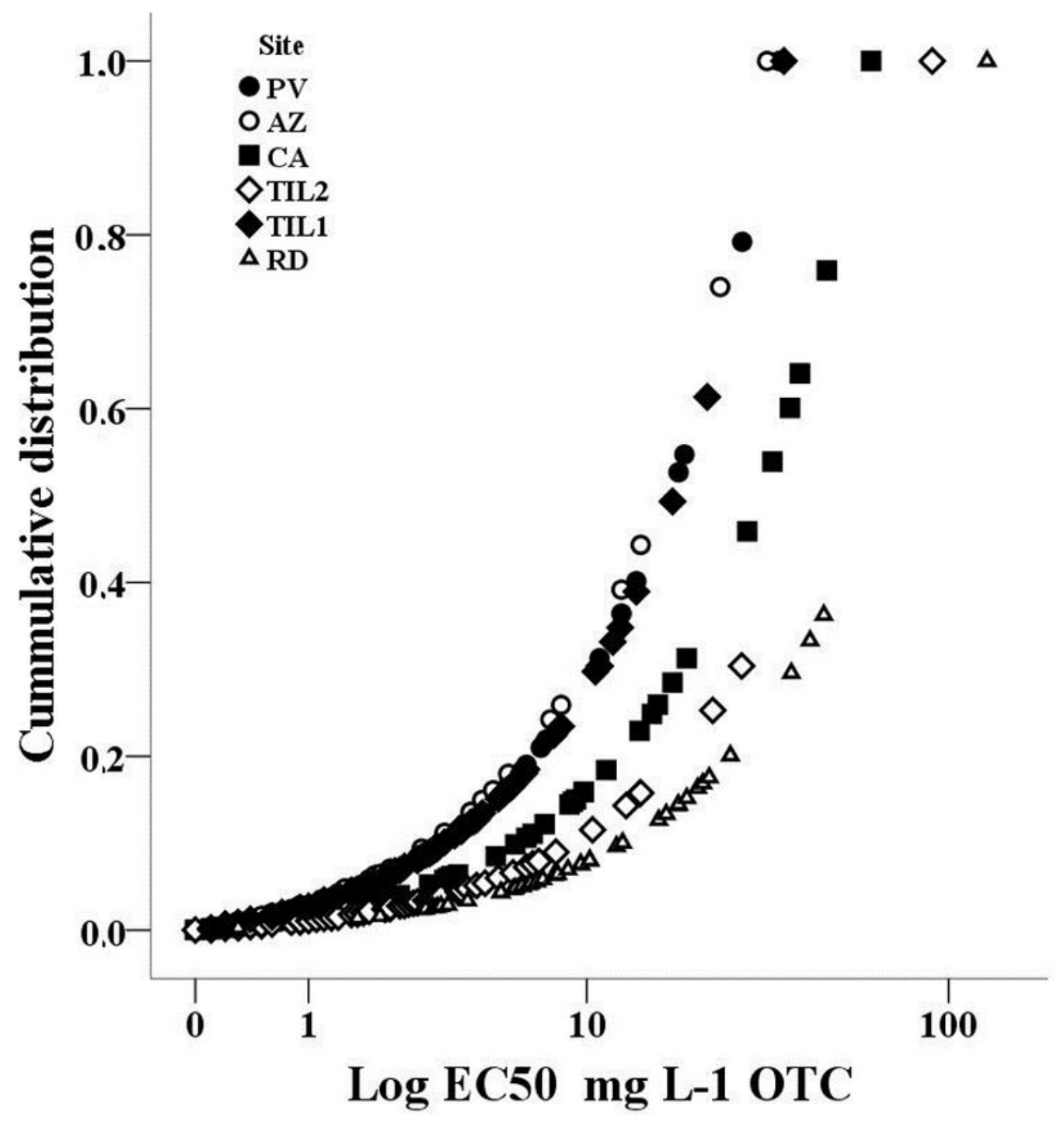




\section{Figure 3}

Figure 3.

Plate counts of culturable OTC-resistant bacteria of sediment bacterial communities from agroecosystems and a protected wetland. PV=Palo Verde (wetland), AZ= Rice farm drainage, TIL2= Effluent into tilapia farm, TIL1= Drainage of treated tilapia farm effluent, $\mathrm{RD} 2=$ Swine farm oxidation lagoon

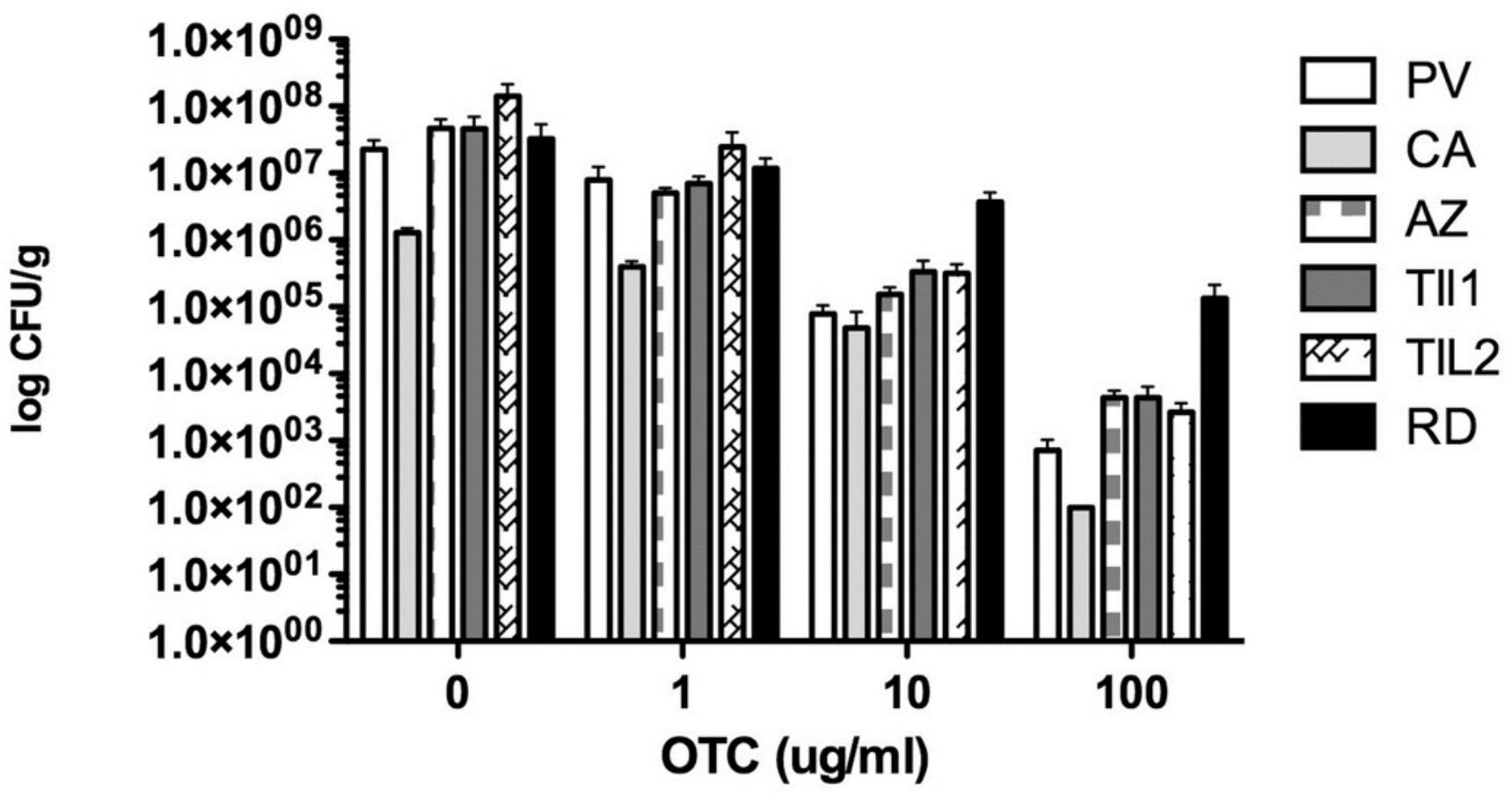

